\title{
Discursive Practice in Online Learning by Using Zoom Meeting on COVID-19
}

\author{
Puput Anipon \\ Universitas Negeri Padang \\ email:puputanipon5@gmail.com
}

\begin{abstract}
Since November 2019 COVID-19 virus spread, all activity chance totals especially in Education. Especially in Indonesia applied online learning, the famous application use is Zoom Meeting. I'm as researcher interested analyze how interaction and communication teacher and student in Zoom application, then want find out how Zoom application in learning media present the discursive practice especially between teacher and student, last how student and teacher construct discursive practice use Zoom application. This research aims to find out how discursive practice present in full online class, especially in English class by using Zoom application. This descriptive qualitative study used interview and observation methodology. Twenty six students from English Language Education Study Program, Magister Program of UNP academic year 2021 participated in this study. Based on observed conducted by researcher in class A and B that use Zoom platform in full online learning toward discursive practice. Researcher found discursive practice can present in the class, although in virtual class. Discursive practice in online class by using Zoom application beyond expectation lecturer and student communicate and interaction well with menu that provide by zoom. It can conclude by researcher that the discursive practice can present although in virtual class.
\end{abstract}

Keywords: COVID-19, Zoom Meeting Aplication, E-learning, Interaction, Discursive Practice

\section{Introduction}

As we know Since November 2019, the Virus named COVID-19 spread whole world start from China. In 11 March 2020 World Health Organizations stated that COVID-19 is pandemic. All activity in the world chance totally, Almost country in the world adapt lockdown, quarantine, self- isolation, work from home, unemployment number and especially in Education. Since March almost educational institutions educators, professors, trainers, instructors, got shock and fear, step by step tried to many ways to avoid a total stop in teaching learning for all over the country, and then tried another ways for leaners study in online class. Educator applied many ways in teaching online. Many application provide by online technology such as: video meeting and online chat applications, software platforms, such as Skype, Google Duo, Hangouts, WhatsApp and Zoom , with limitations available, were applied by teacher and student.

But especially In Indonesia the famous application use is Zoom Meeting. Zoom meeting is a platform video online that provide people communicate and interaction in virtual online. This application is free and easy to use. Cause of that in Indonesia Zoom application appropriate for student and teacher Indonesia. Like ASI (Asosiasi Survey Indonesia) survey, about Media online video in learning, majority used Zoom 57 \% On Saturday 17 October 2020 In Jakarta. Based number of user Zoom very high, So that, I'm as researcher interested analyze how interaction and communication teacher and student in Zoom application. 
DOI: https://doi.org/10.24036/icolp.v1i1.35

Singh \& Thurman, 2019 defined online learning that "learning experiences in synchronous or asynchronous environments using different devices (e.g., mobile phones, laptops, etc.) with internet access. In these environments, students can be anywhere (independent) to learn and interact with instructors and other students". Then according Hanks (1996), Levinson (2006a, 2006b) discursive practice is personals' proficiency inclusion in discursive practices appeals, on other side, a leaning on ethnographically-based, practice-specific dispositions and expectance. As we know, in nowadays both of them go on together in full online class especially English class, since pandemic spread in the world by using famous application is Zoom meeting platform. So researcher interest in this situation is it discursive practice can present in full online learning.

The researcher not yet found a research like this before, so the researcher very interested investigate the discursive practice present in online class, especially in English Language Education Study Program, Magister Program of UNP academic year 2021 students. Then want find out how Zoom application in learning media present the discursive practice between lecture and student. For the last how student and teacher construct discursive practice use Zoom application. This research conduct to analyze and inform to reader how discursive practice present in online class, then how interaction lecture and students by using zoom application.

\section{Online Learning or E-Learning}

Increase developments in technology made space in education more easy and simple (McBrien et al., 2009). "Most of the terms (online learning, open learning, web-based learning, computer-mediated learning, blended learning, m-learning, for ex.) have in common the ability to use a computer connected to a network, that offers the possibility to learn from anywhere, anytime, in any rhythm, with any means" (Cojocariu et al., 2014). Online teaching for now days could be called as a instruments that shall build learning process tend to student-centered, more innovatively, and even more flexibility.

Online learning is often calls as "learning experiences in synchronous or asynchronous environments using different devices (e.g., mobile phones, laptops, etc.) with internet access. In these environments, students can be anywhere (independent) to learn and interact with instructors and other students" (Singh $\&$ Thurman, 2019). The synchronous teaching environment is arrange in experience that leaners feels in live classes, there are real-time interactions among educators and students, and there is a probably of fast responds, where asynchronous teaching situation are not appropriate arrange. In likely a teaching environment, teaching value is not provide in form of directly classes; it is provide at unlike teaching systems and forums. Instantly respond and quick feedback are impossible bellow such an conditions (Littlefield, 2018).

We could conclude that online learning is only one option that we got in situation COVID-19. Online learning be a solution in learning around the world. The online learning provide facilitate for our learning during pandemic especially Zoom application.

\section{Zoom Meeting Application}

Zoom Video Communication Inc., an online video meeting application, that used by many people in academic department since COVID-19 pandemic spread then bring us move to online way of instruction (Serhan, 2020; Tsai et al., 2020). Video conference probably for synchronous communicate by audio and visual data among two or more groups of people (Correia et al., 2020). Zoom could replace classroom be virtual class (Henriksen et al., 2020). The feature, likely the access to record mode, share screens and files to participant, breakout rooms for big conference and vote feature, that's all interactive modes for participants or members attend to replace common class ways (Zoom Video Communications, 2021).

To applied online technology, like Zoom applications, could be difficult, mostly for teacher unfamiliar or not comfortable with technology feature (Ramlo, 2021). In line especially correct when the 
DOI: https://doi.org/10.24036/icolp.v1i1.35

transformations is immediately and could control the success of Zoom applications at an institution grade. Furthermore, aspects like awareness with technology, teacher and students compliance to transformation and leaners accessibility have a big impact on the successfully practice of applications, like Zoom (Ali, 2020). Almost academic side inform that online direction mode are lowly to commonly classroom directions (Broussard and Wilson, 2018; Markova et al., 2017). Besides that, Holges et al. (2020) focus on awareness shall be used in evaluate the achievement of online learning impression in urgency, like COVID-19, because wary material design would not have applied. Time problem while these urgent condition might avoid faculty from maximum applied online learning possibility (Holges et al., 2020).

\section{Language Learning as Discursive Practice}

Personal proficiency inclusion in discursive practices request, in side, a reliance on ethnographically-grounded, practice-specific dispositions and expectancy (Hanks, 1996; Levinson, 2006a, 2006b).The proficiency personals lead to their discursive practices is expand by continued impression in their practices with others, more practices members (Tomasello, 1999, 2003; Vygotsky, 1978, 1981, 1986). Mean factors about these practices to the design and settings of personal science are their repeated essential and the allocation and frequency with which sequences of movement and their particular linguistic aspects are meeting in the discursive practice. For more frequently, trusted and constants to apply of special system and structures is in the unfolding movement of the practical ; the more like they would be borne and remember.

The expansion of personal speech science and proficiency is intimate connected to the discursive worlds in which personals engage; the practices in which they get through their term not simple increase their personal development. Although they primarily form and change it. The systems and settings applied to finished movement in practices purpose as 'carriers of sociocultural patterns and knowledge' (Wertsch, 1994), and the proceeds collections of personal speech knowledge and skills describe at the same time 'their socialization and individuation' (Williams, 1977). Line with expert above language learning as discursive practice is about competence each individual through experience in their practice with other and it specific linguistics components that needs action and practice.

\section{Methods}

This study was descriptive qualitative study used interview and observation methodology. Twenty six students from English Language Education Study Program, Magister Program of UNP academic year 2021 participated in this study. Based on observed conducted by researcher in class A and B that use Zoom platform in full online learning toward discursive practice. The researcher was analyze:

1. How Zoom application in learning media present the discursive practice especially between lecturer and student?

2. How student and lecturer construct discursive practice use Zoom application?

Based the question the researcher analyze the discursive practice in online learning while learning process. The researcher make conclusion about discursive practice in online learning by using zoom meeting.

\section{Result and Discussion}

Based on research was conduct to 26 participants, English Language Education Study Program, Magister Program of UNP academic year 2021 students. Online class divide into two class : class A and class B. Based on observed by researcher in class A and B that use Zoom platform in online learning toward discursive practice. Researcher found discursive practice can present in the class, although in virtual class. 
DOI: https://doi.org/10.24036/icolp.v1i1.35

According student that interviewed when asked how Zoom application present discursive practices between lecture and student. More than $80 \%$ stated that discursive practice can present between lecture and students. As mention one of them:

"I think Zoom application better than another application available in internet, Zoom easier in feature and operate. Then about discursive practice between lecture and students almost can present like commonly class. Just connection problem maybe sometimes disturbing us"

Discursive practice in online class by using Zoom application beyond expectation, lecturer and student communicate and interaction well with menu that provide by zoom. The menu in application help lecture and students construct discursive practice in virtual class. For example: "rise hand" feature, with it the student rise hand with quiet and stand in line. The discussion in class will under control and they can understand each other. As participant respond in interview, when asked about how lecture and student construct discursive practice in online class:

"The application have simple menu and important in online class. Zoom meeting have a 'host' when meeting run. The host can control everything, include if some of us forget turn off microphone, the host can unmute it, then rise hand and chat box too, they helpful for us in interaction each other"

Based on the discussion above we can conclude that online class by using zoom application can effectively do or present discursive practice. For example: Lecture fall or up the tone while teaching or give instruction. While the researcher observed lecture and student in Zoom meeting class all student can give respond like teacher want by using gesture, tone, eyed movement etc. By using zoom application activity in learning process can run as well as expect.

Finally it states that lecturer and student can present and construct discursive practice in virtual class with communication and interaction in the class by using Zoom application. They can understand each other and make good relationship between teacher and student. All activity and teaching learning process had provided by zoom platform, with easy feature. Although it virtual class but lecture and student can see each other and comprehend each other.

But in other hand the external condition; often make communication lecturer and student disturbing. Such as: Bad connection provider that used by student and lecturer while online. It really disturbing them, because sometimes make misunderstanding between lecturer and students in teaching learning process.

\section{Conclusion}

The findings describe how discursive practice can present and construct in online class. The researcher found that the discursive practice can present although in virtual class by using Zoom platform. All discussion above can answer the objective this research, the question research from researcher. The effectiveness depend on student and lecture, how they understand and relationship each other. All activity, communication and interaction in virtual class will present discursive practice for lecture and student. So that makes a perfect atmosphere while learning process. Then the connection it's a serious problem that must be solved by provider and government.

The findings, hope can be a new topic and new point of view from lecture, student, university, government and developer. Then this finding can be a consideration for lecture in applied online learning in the class, for confortable class for student while teaching activity. Furthermore governments can development any planning and policy in online learning for situation like now. In order online learning if extend in future, the academic objective can reach by lecture and students then get positive impact in both of side. 


\section{References}

Ali, W. (2020). Online and remote learning in higher education institutes: a necessity in light of COVID19 pandemic. High. Educ. Stud., 10 (3), 16-25. https://doi.org/ 10.5539/hes.v10n3p16.

Broussard, L., Wilson, K., (2018). Nursing faculty attitudes and practices related to online teaching. Nurs. Educ. Perspect., 39(1), 40-42. https://doi.org/10.1097/01. nep.0000000000000208.

Cojocariu, V. M., Lazar, I., Nedeff, V., \& Lazar, G. (2014). SWOT analysis of e-learning educational services from the perspective of their beneficiaries. Procedia-Social and Behavioral Sciences, 116, 1999-2003.

Correia, A.P., Liu, C., Xu, F. (2020). Evaluating videoconferencing systems for the quality of the educational experience. Distance Educ., 41(4), 429-452.

Hanks, W. (1996), Language and Communicative Practices. Boulder: Westview Press.

Henriksen, D., Creely, E., Henderson, M., (2020). Folk pedagogies for teacher transitions: approaches to synchronous online learning in the wake of COVID-19. J. Technol. Teach. Educ., 28 (2), 201209. Retrieved from. (https://www.learntechlib.org/ primary/p/216179/).

Holges, C., Moore, S., Lockee, B., Trust, T., Bond, A. (2020). The difference between emergency remote teaching and online learning. Retrieved from (https://er.educ ause.edu/articles/2020/3/thedifference-between-emergency-remote-teaching-andonline-learning).

Littlefield, J. (2018). The difference between synchronous and asynchronous distance learning. https://www.thoughtco.com/synchronous-distance-learning-asynchronousdistance-learning$\underline{1097959 .}$.

McBrien, J. L., Cheng, R., \& Jones, P. (2009). Virtual spaces: Employing a synchronous online classroom to facilitate student engagement in online learning. The International Review of Research in Open and Distributed Learning, 10(3), 1-17.

Ramlo, S., 2021. The coronavirus and higher education: faculty viewpoints about universities moving online during a worldwide pandemic. Innov. High. Educ. 46, 241-259. https://doi.org/10.1007/s10755-020-09532-8.

Serhan, D. (2020). Transitioning from face-to-face to remote learning: students' attitudes and perceptions of using Zoom during COVID-19 pandemic. Int. J. Technol. Educ. Sci. (IJTES) 4 (4), 335-342. https://doi.org/10.46328/ijtes.v4i4.148.

Singh, V., \& Thurman, A. (2019). How many ways can we define online learning? A systematic literature review of definitions of online learning (1988-2018). American Journal of Distance Education, 33(4), 289-306.

Tomasello, M. (1999), The Cultural Origins of Human Cognition. Cambridge: Harvard University Press. -(2003), Constructing a Language: A Usage-Based Theory of Language Acquisition. Cambridge, MA: Harvard University Press. 
Proceeding of International Conference on Language Pedagogy

Vol. 1. No. 1, pp. 165-170, 2021

ISSN: 2809-4808

DOI: https://doi.org/10.24036/icolp.v1i1.35

Wertsch, J. (1994), 'The primacy of mediated action in sociocultural studies' Mind, Culture, and Activity, $1,202-208$.

Williams, R. (1977), Marxism and Literature. Oxford: Oxford University Press. 